\title{
TO STUDY THE EFFECT OF IRON DEFICIENCY ANAEMIA ON HbA1C IN NON-DIABETIC
}

\author{
Shailendra Kumar Manjhvar1, Beerbhan Singh², Ajeet Singh Niranjan ${ }^{3}$
}

${ }^{1}$ Associate Professor, Department of Medicine, Shyam Shah Medical College and Sanjay Gandhi Memorial Hospital, Rewa. ${ }_{2}^{2}$ Assistant Professor, Department of Medicine, Shyam Shah Medical College and Sanjay Gandhi Memorial Hospital, Rewa. 3 Junior Resident, Department of Medicine, Shyam Shah Medical College and Sanjay Gandhi Memorial Hospital, Rewa.

\section{BACKGROUND}

ABSTRACT

The most common form of anaemia plaguing our country is Iron deficiency anaemia. The extent of diabetic control is measured by HbA1c, which is the average blood glucose level of the patient over the past 3 months. HbA1c levels depend upon a multitude of factors such as the presence of different types of haemoglobins, any haemolytic anaemia, any nutritional deficiency anaemias, uraemia, pregnancy and acute blood loss. Older studies suggest that Iron deficiency anaemia is another one of the factors affecting HbA1C levels.

We conducted a prospective observational study to analyse the effect of iron deficiency anaemia on glycated haemoglobin (HbA1c) in non-diabetic Indians.

\section{MATERIALS AND METHODS}

A prospective observational study on 500 iron deficiency patient cases was carried out in SGM Hospital, Rewa from the period July 2016 to June 2017. Exclusion and inclusion criteria were used to recruit cases from the wards and OPDs of the hospital. Appropriate descriptive statistics was used to analyse the data.

\section{RESULTS}

The mean HbA1c level in the patients with iron deficiency anaemia (IDA) is $6.19 \pm 0.58$. In our study, we found increased severity of iron deficiency anaemia is associated with increased level of HbA1c. In female patients (379 out of 500) mild anaemia (73)mean HbA1c 5.79 \pm 0.35; moderate anaemia (242)- mean HbA1c 6.16 \pm 0.39 ; and severe anaemia (64)- mean HbA1c 7.2 \pm 0.46 . In our study in male patients (121 out of 500) mild anaemia (34)- mean HbA1c 5.79 \pm 0.35 ; moderate anaemia (73)- mean HbA1c $5.86 \pm 0.26$; and severe anaemia (14)- mean HbA1c $6.80 \pm 0.354$.

\section{CONCLUSION}

It was found that IDA was more common among the reproductive age group women. It was associated with shift in the HbA1c levels to higher side with severity of anaemia.

\section{KEYWORDS}

Non-Diabetic Patient, Glycosylated Haemoglobin, Iron Deficiency Anaemia.

HOW TO CITE THIS ARTICLE: Manjhvar SK, Singh B, Niranjan AS. To study the effect of iron deficiency anaemia on HbA1c in nondiabetic. J. Evolution Med. Dent. Sci. 2017;6(94):6863-6867, DOI: 10.14260/jemds/2017/1487

\section{BACKGROUND}

HbA1c is used as the gold standard for monitoring glycaemic control and used as a foresee of diabetic complications.[1] Throughout the circulatory life of the red blood cell, HbA1c is formed continuously by adjoining of glucose to the $\mathrm{N}$ terminal of the haemoglobin beta chain.

This process is non-enzymatic and reflects the average exposure of haemoglobin to glucose over a period of nearly 70 - 90 days. HbA1c has been defined as the fast fraction haemoglobin (HbA1a, A1c), which elute first during column chromatography with cation-exchange resin. HbA1c levels are not influenced by only blood glucose levels.

Any condition that decreases the average length of life of erythrocytes is also responsible for decreased $\mathrm{HbA1c}$ level. These conditions are acute or chronic blood loss, sickle cell anaemia, thalassaemias, haemolytic anaemia, aplastic anaemia, splenectomy, pregnancy, chronic kidney diseases, vitamin-B12 and folate deficiency anaemia.[2,3]

'Financial or Other Competing Interest': None.

Submission 21-10-2017, Peer Review 01-12-2017,

Acceptance 06-12-2017, Published 18-12-2017.

Corresponding Author:

Dr. Beerbhan Singh,

F-11, Old Doctor Colony,

Medical College Campus, Rewa-486001

E-mail: drbeerbhansingh@gmail.com

DOI: $10.14260 /$ jemds $/ 2017 / 1487$
Falsely raised HbA1c can be seen during the increased lifespan of circulating erythrocyte. These conditions are alcoholism, hyperbilirubinaemia and iron deficiency anaemia. ${ }^{4,5]}$ According to WHO, iron deficiency is the commonest of all deficiency diseases worldwide. [6]

Iron deficiency anaemia is the most common in India.[7] Some studies show that HbA1c levels are increased in iron deficiency anaemia and attempted to explain on the basis of both modifications to the structure of haemoglobin and levels of HbA1c in old and new red blood cells.[8,9]

According to some studies, there were no differences between HbA1c levels of anaemic patients and controls.[10,11] Study conducted by El-Agouza L et al showed that higher level of HbA1c seen in patients suffering from iron deficiency anaemia and with correction of anaemia fall in $\mathrm{HbA1c}$ is seen.[12] Recently, Sinha et al showed that HbA1c levels and absolute HbA1c levels increased with treatment of iron deficiency anaemia.[13]

\section{MATERIALS AND METHODS \\ Type of Study}

Prospective observational study.

\section{Place of Study}

Department of Medicine, SS Medical College and SGMH, Rewa, MP. 


\section{Sample Size}

The studies was carried out on 500 non-diabetic patients with iron deficiency anaemia attending the OPD and admitted in medicine ward.

\section{Study Duration}

From July 2016 to June 2017.

The iron deficiency anaemic patients were recruited on their haemoglobin levels $(\mathrm{Hb}<12$ in non-pregnant female and 13 in male), ferritin levels ( $<9 \mathrm{ng} / \mathrm{mL}$ for women, $<15 \mathrm{ng} / \mathrm{mL}$ for men) and on their peripheral blood smears which indicate iron deficiency anaemia. ${ }^{14}$

The levels of haemoglobin, mean corpuscular haemoglobin $(\mathrm{MCH})$, haematocrit, mean corpuscular volume (MCV), mean corpuscular haemoglobin concentration (MCHC), platelet count, total leucocyte count (TLC) and differential leucocyte count (DLC) were measured by an automated analyser.

On the basis of haemoglobin level patients were categorised as having mild, moderate or severe anaemia. Mild anaemia (male patients $12-12.9 \mathrm{gm} / \mathrm{dL}$ and female patients 11 - $11.9 \mathrm{gm} / \mathrm{dL})$.

Moderate anaemia (male patients $9-11.9 \mathrm{gm} / \mathrm{dL}$ and female patients $8-10.9 \mathrm{gm} / \mathrm{dL}$ ) and severe anaemia (male patients $<9 \mathrm{gm} / \mathrm{dL}$ and female patients $<8 \mathrm{gm} / \mathrm{dL}$ ). Those with predominantly microcytic indices (MCV $<80 \mathrm{fL}$ ), hypochromic indices ( $\mathrm{MCH}<26 \mathrm{pg} /$ cell) were considered to have iron deficiency anaemia. ${ }^{14}$ Normal HbA1c in nondiabetic individuals is $<5.6 \%{ }^{15}$

\section{Inclusion Criteria}

1. Patient without diabetes.

2. Patient belonging to rural and urban area.

3. > 18 yrs. of age.

4. Giving consent for study.

\section{Exclusion Criteria}

Patients with history of acute or chronic blood loss, haemolytic anaemia, haemoglobinopathies, kidney diseases, diabetics, pregnancy, chronic alcohol ingestion and impaired glucose tolerance are excluded.

The blood specimens were drawn after an 8-hourly fasting period. A Sysmex automated haematology analyser (MINDRAY) was used for the whole blood counts [haemoglobin (Hb), mean corpuscular volume (MCV) and mean corpuscular haemoglobin $(\mathrm{MCH})]$. The serum ferritin levels were measured by using a Diatek kit in a Labowind semiautomated analyser and the peripheral blood smears were examined in all the patients. The HbA1c levels were determined by turbidimetric immunoinhibition.

\section{Statistical Analysis}

Continuous data were expressed as mean \pm SD and median, and analysed by unpaired ' $\mathrm{t}$ ' test. Categorical data was represented as numbers and percentages and was analysed using the Chi-square test. $\mathrm{P}$ value of 0.05 or less was considered as statistically significant. Study was analysed by SPSS version 22.0.

\section{RESULTS}

In our study mean age is $37.10 \pm 12.39$, mean serum ferritin is $18.45 \pm 6.39$, mean haemoglobin is $9.51 \pm 1.86$, mean HbA1c is $6.19 \pm 0.58$, mean MCV is $68.22 \pm 6.03$, mean MCH is $22.87 \pm 1.77$, mean FBS is $81.26 \pm 6.99$, mean PPBS is 112.65 \pm 10.50 . In our study, increase in severity of anaemia is associated with increased $\mathrm{HbA1c}$ level.

In our study in female patient (379 out of 500)- mild anaemia (73)- mean HbA1c $5.79 \pm 0.35$; moderate anaemia (242)- mean HbA1c $6.16 \pm 0.39$; and severe anaemia (64)mean HbA1c $7.2 \pm 0.46$.

In our study in male patient (121 out of 500)- mild anaemia (34)- mean HbA1c $5.79 \pm 0.35$; moderate anaemia (73)- mean HbA1c $5.86 \pm 0.26$; severe anaemia (14)- mean HbA1c $6.80 \pm 0.354$.

Out of 500 cases 107 (21.4\%), 315 (63\%) and 78 (15.6\%) have mild, moderate and severe anaemia respectively. Out of 121 male patients, 34 (28.09\%) have mild anaemia, 73 $(60.33 \%)$ have moderate anaemia and 14 (11.57\%) have severe anaemia. Out of 379 female patients, 73 (19.26\%) have mild anaemia, $242(63.85 \%)$ have moderate anaemia and $64(16.88 \%)$ have severe anaemia.

Out of 500 patients, easy fatigability are present in 100\% (500), dyspnoea on exertion present in 75\% (375), melena present in $22.6 \%$ (113), giddiness in $20.2 \%$ (101), palpitation in $15.6 \%$ (78) and fever present in $13.4 \%$ (67). Out of 500 patients $500(100 \%)$ patients have pallor, $134(26.8 \%)$ have bald tongue, $136(27.2 \%)$ have koilonychia, 47 (9.4\%) have ejection systolic murmur and $43(8.6 \%)$ have bilateral pedal oedema.

\begin{tabular}{|c|c|}
\hline Parameter in Study & Mean Value in Study \\
\hline HbA1c (\%) & $6.19 \pm 0.58$ \\
\hline Serum ferritin (ng/ mL) & $18.45 \pm 6.39$ \\
\hline Haemoglobin (gm/ dL) & $9.51 \pm 1.86$ \\
\hline MCV (fL) & $68.22 \pm 6.03$ \\
\hline MCH (pg/ cell) & $22.87 \pm 1.77$ \\
\hline FBS (mg/ dL) & $81.26 \pm 6.99$ \\
\hline PPBS (mg/ dL) & $112.65 \pm 10.50$ \\
\hline Mean Age (in yrs.) & $37.10 \pm 12.39$ \\
\hline \multicolumn{2}{|c|}{ Table 1 } \\
\hline
\end{tabular}

\begin{tabular}{|c|c|c|c|}
\hline Sl. No. & Gender & Number of Cases & Percentage \\
\hline 1 & Male & 121 & 24.2 \\
\hline 2 & Female & 379 & 75.8 \\
\hline \multicolumn{4}{|c|}{ Table 2. Distribution of Cases according to Gender } \\
\hline \multicolumn{4}{|c}{}
\end{tabular}

Out of 500 patients, female patients are 379 (75.8\%) and male patients are 121 (24.2\%).

\begin{tabular}{|c|c|c|c|}
\hline Sl. No. & Residence & Number of Cases & Percentage \\
\hline 1 & Urban & 145 & 29 \\
\hline 2 & Rural & 355 & 71 \\
\hline \multicolumn{3}{|c|}{ Table 3. Distribution of Cases according to Domicile } \\
\hline
\end{tabular}

Out of 500 patients, 355 (71\%) belonged to rural community and 145 (29\%) belonged to urban community. 


\begin{tabular}{|c|c|c|c|}
\hline Sl. No. & Anaemia & Number of Cases & Percentage \\
\hline 1 & Mild & 107 & 21.4 \\
\hline 2 & Moderate & 315 & 63.0 \\
\hline \multirow[t]{2}{*}{3} & Severe & 78 & 15.6 \\
\hline & Total & 500 & 100.0 \\
\hline \multicolumn{4}{|c|}{$\begin{array}{c}\text { Table 4. Distribution of Cases according to } \\
\text { Severity of Anaemia }\end{array}$} \\
\hline
\end{tabular}

Out of 500 cases 107 (21.4\%), 315 (63\%) and 78 (15.6\%) have mild, moderate and severe anaemia respectively.

\begin{tabular}{|c|c|c|c|}
\hline Sl. No. & Symptoms & Number of Cases & $\mathbf{\%}$ \\
\hline 1 & Easy fatigability & 500 & 100 \\
\hline 2 & Dyspnoea on exertion & 375 & 75 \\
\hline 3 & Fever & 67 & 13.4 \\
\hline 4 & Giddiness & 101 & 20.2 \\
\hline 5 & Melena & 113 & 22.6 \\
\hline 6 & Palpitation & 78 & 15.6 \\
\hline \multicolumn{2}{|c|}{ Table 5. Distribution of Cases according to Symptoms } \\
\hline
\end{tabular}

Out of 500 patients, easy fatigability is present in $100 \%$ (500), dyspnoea on exertion present in $75 \%$ (375), melena present in $22.6 \%$ (113), giddiness in $20.2 \%$ (101), palpitation in $15.6 \%$ (78) and fever present in $13.4 \%$ (67).

\begin{tabular}{|c|c|c|c|}
\hline Sl. No. & Sign & Number of Cases & Percentage \\
\hline 1 & Pallor & 500 & 100 \\
\hline 2 & Bald tongue & 134 & 26.8 \\
\hline 3 & Koilonychia & 136 & 27.2 \\
\hline 4 & $\begin{array}{c}\text { Ejection systolic } \\
\text { murmur }\end{array}$ & 47 & 9.4 \\
\hline 5 & Pedal oedema & 43 & 8.6 \\
\hline \multicolumn{3}{|c|}{ Table 6. Distribution of Cases according to Sign } \\
\hline
\end{tabular}

Out of 500 patients $500(100 \%)$ patient have pallor, 134 (26.8\%) have bald tongue, $136(27.2 \%)$ have koilonychia, 47 (9.4\%) have ejection systolic murmur and 43 (8.6\%) have bilateral pedal oedema.

\begin{tabular}{|c|c|c|c|}
\hline Sl. No. & Addiction & Number of Cases & Percentage \\
\hline 1 & Tobacco & 156 & 31.2 \\
\hline 2 & Smoking & 49 & 9.8 \\
\hline 5 & Tobacco + Smoking & 47 & 9.4 \\
\hline \multicolumn{2}{|c|}{ Table 7. Distribution of Cases according to Addiction } \\
\hline
\end{tabular}

Above table shows that $156(31.2 \%)$ are addicted for tobacco, 49 (9.8\%) are addicted for smoking, addiction for both was present in 47 (9.4\%).

\begin{tabular}{|c|c|c|c|c|c|}
\hline \multirow{2}{*}{ Sl. No. } & \multirow{2}{*}{$\begin{array}{c}\text { Age Group } \\
\text { (In Yrs.) }\end{array}$} & Mild & Moderate & Severe & Total \\
\cline { 3 - 6 } & 18 to 30 & $32(29.9 \%)$ & $104(33.01 \%)$ & $29(37.1 \%)$ & $165(33 \%)$ \\
\hline 1 & 31 to 40 & $30(28.03 \%)$ & $98(31.1 \%)$ & $29(37.1 \%)$ & $157(31.4 \%)$ \\
\hline 2 & 41 to 50 & $18(16.8 \%)$ & $72(22.8 \%)$ & $12(15.3 \%)$ & $102(20.4 \%)$ \\
\hline 3 & 51 to 60 & $14(13.08 \%)$ & $30(9.5 \%)$ & $06(7.6 \%)$ & $50(10 \%)$ \\
\hline 4 & $>60$ & $13(12.01 \%)$ & $11(3.49 \%)$ & $02(2.5 \%)$ & $26(5.2 \%)$ \\
\hline 5 & \multicolumn{7}{r}{ Table 8. Distribution of Age Group according to Severity of Anaemia } & 500 \\
\hline
\end{tabular}

Chi-square $=18.764, \mathrm{P}$ value $=0.0162$ significantly associated .

It is evident from the above table that maximum number of patients are present in 18 - 30 years of age group, that is 165 (33\%) followed by 157 (31.4\%) in 31 - 40 years of age group, 102 (20.4\%) in 41 - 50 years of age group, 50 (10\%) in 51 to 60 years of age group and minimum number of patients are present in $>60$ years of age group $26(5.2 \%)$.

\begin{tabular}{|c|c|c|c|c|c|}
\hline \multirow{2}{*}{ Sl. No. } & \multirow{2}{*}{ Male/ Anaemia } & \multicolumn{4}{|c|}{ HbA1c } \\
\hline & & $\leq 5.5$ & 5.6 to 6.5 & 6.6 to 7.5 & $>7.5$ \\
\hline 1 & Mild anaemia $<12$ to $12.9 \mathrm{gm} / \mathrm{dL}(\mathrm{n}=34,28.09 \%)$ & $10(29.41 \%)$ & $24(70.58 \%)$ & 0 & 0 \\
\hline 2 & Moderate anaemia 9 to $11.9 \mathrm{gm} / \mathrm{dL}(\mathrm{n}=73,60.33 \%)$ & $3(4.10 \%)$ & $68(93.15 \%)$ & $2(2.73 \%)$ & 0 \\
\hline 3 & Severe anaemia $<9 \mathrm{gm} / \mathrm{dL}(\mathrm{n}=14,11.57 \%)$ & 0 & $3(21.4 \%)$ & $10(71.42)$ & $1(7.14 \%)$ \\
\hline & Total $=121$ & 13(10.74\%) & $95(78.5 \%)$ & $12(9.91 \%)$ & $1(0.82 \%)$ \\
\hline
\end{tabular}

Chi-square $=91.817, \mathrm{P}=<0.0001$ statistically significant.

Above table shows that out of 121 male patients, 70.58\% (24 of 34) patients with mild anaemia have HbA1c between 5.6\% - 6.5\% and there are no patients in HbA1c range between 6.6\% - 7.5\%, whereas 93.15\%(68 of 73) patients with moderate anaemia have HbA1c between 5.6\% - 6.5\% and 2.73\% (2 of 73) patients have HbA1c between 6.6\% - 7.5\%, 71.42\% (10 of 14) patients in a group of severe anaemia have HbA1c range between $6.6 \%-7.5 \%$.

\begin{tabular}{|c|c|c|c|c|c|}
\hline \multirow{2}{*}{ SI. No. } & \multirow{2}{*}{ Female/ Anaemia } & \multicolumn{4}{|c|}{ HbA1c } \\
\hline & & $\leq 5.5$ & 5.6 to 6.5 & 6.6 to 7.5 & $>7.5$ \\
\hline 1 & Mild anaemia < 11 to $11.9 \mathrm{gm} / \mathrm{dL}(\mathrm{n}=73,19.26 \%)$ & $23(31.5 \%)$ & $50(68.49 \%)$ & 0 & 0 \\
\hline 2 & $\begin{array}{c}\text { Moderate anaemia } 8 \text { to } 10.9 \mathrm{gm} / \mathrm{dL}(\mathrm{n}=242 \\
63.85 \%)\end{array}$ & $7(2.89 \%)$ & $189(78.09)$ & $46(19 \%)$ & 0 \\
\hline 3 & Severe anaemia $<8 \mathrm{gm} / \mathrm{dL}(\mathrm{n}=64,16.88 \%)$ & 0 & $2(3.12 \%)$ & $46(71.87 \%)$ & $16(25 \%)$ \\
\hline & Total $=379$ & $30(7.91)$ & $241(63.58 \%)$ & $92(24.27 \%)$ & $16(4.22 \%)$ \\
\hline
\end{tabular}

Chi-square $=268.16, \mathrm{P}=<0.0001$ statistically significant. 
Above table shows that out of 379 female patients, $68.49 \%$ (50 of 73) patients with mild anaemia have HbA1c between $5.6 \%-6.5 \%$ and there are no patients in $\mathrm{HbA} 1 \mathrm{c}$ range between $6.6 \%-7.5 \%$, whereas $78.09 \%$ (189 of 242) patients with moderate anaemia have $\mathrm{HbA1c}$ between $5.6 \%$ $6.5 \%$ and $19 \%$ ( 46 of 242 ) patients have HbA1c between $6.6 \%-7.5 \%, 71.87 \%$ (46 of 64 ) patients in a group of severe anaemia have $\mathrm{HbA} 1 \mathrm{c}$ range between $6.6 \%-7.5 \%$ and $25 \%$ (16 of 64) patients in group of severe anaemia have HbA1c > $7.5 \%$.

\begin{tabular}{|c|c|c|}
\hline $\begin{array}{c}\text { Age Group (In } \\
\text { Yrs.) }\end{array}$ & Total Patients & Mean HbA1c \\
\hline $18-30$ yrs. & 165 & $6.23 \pm 0.59$ \\
\hline $31-40$ yrs. & 157 & $6.27 \pm 0.60$ \\
\hline $41-50$ yrs. & 102 & $6.14 \pm 0.57$ \\
\hline $51-60$ yrs. & 50 & $6.16 \pm 0.54$ \\
\hline >60 yrs. & 26 & $6.02 \pm 0.47$ \\
\hline Total (n) & $\mathbf{5 0 0}$ & $\mathbf{6 . 1 9} \pm \mathbf{0 . 5 8}$ \\
\hline \multicolumn{2}{|c|}{ Table 11. Mean HbA1c in Different Age Group } \\
\hline
\end{tabular}

In our study, mean $\mathrm{HbA1c}$ value in all 500 patients is 6.19 \pm 0.58 . In 18 - 30 yrs., mean HbA1c is $6.23 \pm 0.59$. In $31-40$ years' age group, mean $\mathrm{HbA} 1 \mathrm{c}$ is $6.27 \pm 0.60$. In 41 - 50 years' age group, mean $\mathrm{HbA1c}$ is $6.14 \pm 0.57$. In $51-60$ years' age group, mean $\mathrm{HbA} 1 \mathrm{c}$ is $6.16 \pm 0.54$. In $>60$ years, mean $\mathrm{HbA} 1 \mathrm{c}$ is $6.02 \pm 0.47$.

$\mathbf{X}$-axis- Severity of anaemia

Y-axis- Mean HbA1c level (\%)

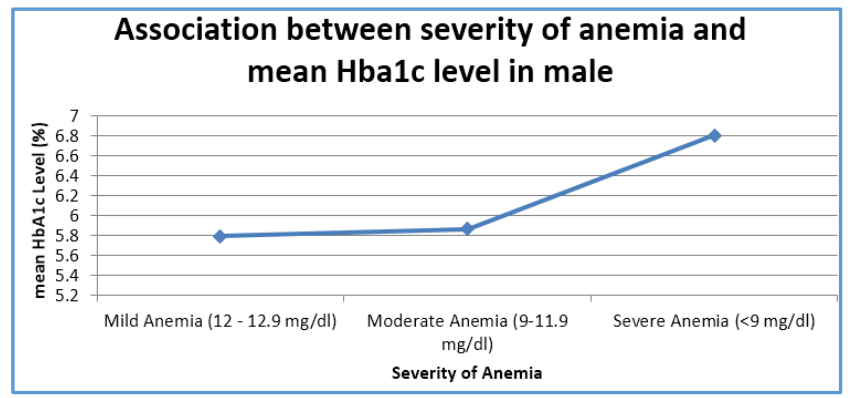

Association between Severity of Anaemia and Hba1c Level in Male

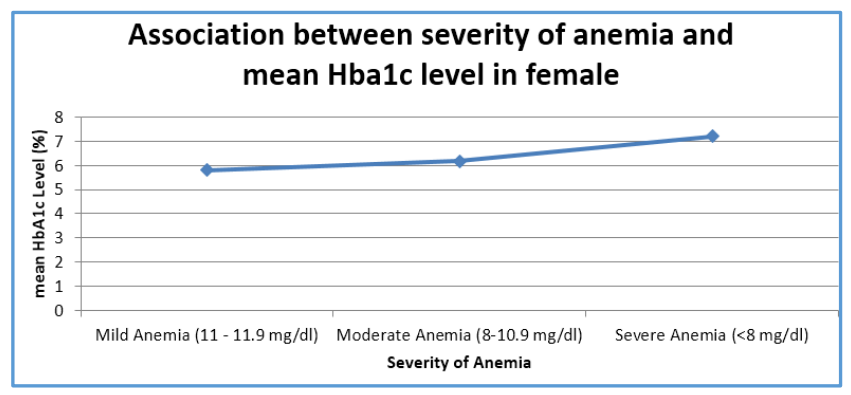

Association between Severity of Anaemia and Hba1c Level in Female

\section{DISCUSSION}

In our study, mean HbA1c value in all 500 patients is $6.19 \pm$ 0.58. In $18-30$ yrs., mean HbA1c is $6.23 \pm 0.59$. In $31-40$ years' age group, mean HbA1c is $6.27 \pm 0.60$. In $41-50$ years' age group, mean $\mathrm{HbA1c}$ is $6.14 \pm 0.57$. In $51-60$ years' age group, mean $\mathrm{HbA} 1 \mathrm{c}$ is $6.16 \pm 0.54$. In $>60$ yrs., mean $\mathrm{HbA} 1 \mathrm{c}$ is $6.02 \pm 0.47$.

El-Agouza et al ${ }^{12}$ and Coban 6 et al showed that HbA1c levels were higher in patients with iron deficiency anaemia and decreased significantly upon treatment with iron. Similar results were also seen in studies carried out by Gram-Hansen et al.11

In Lavanya Rajagopal 16 et al study, non-diabetics with IDA had a mean HbA1c \% (6.84 \pm 0.07$)$, which was significantly higher $(\mathrm{p}<0.05)$ than the non-anaemic group (5.12 \pm 0.04$)$.

The mean HbA1c level was higher in iron deficiency anaemic patient when compared to normal healthy individual in study by Balasubramanian Shanthi et al. ${ }^{17}$

In Alap L Christy et al ${ }^{18}$ study, the mean HbA1c of cases was $6.87 \pm 1.4 \%$, while it was $5.65 \pm 0.69 \%$ in healthy control.

In the Ford ES et al study, ${ }^{19}$ reported no significant difference in mean HbA1C concentration according to the IDA status as well as before and after iron treatment.

In Saudek CD et al study, ${ }^{20}$ suggested that red cell age was unlikely to be a significant factor in explaining the changes in HbA1C levels during the treatment of IDA and believed that the reported differences in $\mathrm{HbA} 1 \mathrm{C}$ concentrations before and after iron supplementation were due to differences in the laboratory methods used for measuring HbA1c.

\section{CONCLUSION}

Glycosylated haemoglobin (HbA1c) values were significantly higher in non-diabetic IDA patients implying that iron deficiency anaemia leads to a rise in the glycosylated haemoglobin values. This may have a practical application in diabetic individuals with iron deficiency anaemia, where glycosylated haemoglobin alone may give a false picture of poor glycaemic control. Therefore, iron deficiency must be corrected before making diagnostic or therapeutic decision based on glycosylated haemoglobin values in diabetes mellitus.

\section{REFERENCES}

[1] Reddy SA, Sachan A, Rao SPVLN, et al. Clinical applications of glycosylated haemoglobin. J Clin Sci Res 2012;2:22-33.

[2] Starkman HS, Wacks M, Soeldner JS, et al. Effect of acute blood loss on glycosylated hemoglobin determination in normal subjects. Diabetes Care 1983;6(3):291-4.

[3] Horton BF, Huisman TH. Studies on the heterogeneity of hemoglobin. Vll. Minor hemoglobin components in hematological disease. Br J Haematol 1965;11(3):296304.

[4] Gallagher EJ, Le Roith D, Bloomgarden Z. Review of hemoglobin $\mathrm{A}(1 \mathrm{c})$ in the management of diabetes. J Diabetes 2009;1(1):9-17.

[5] Sluither WJ, Van Essen LH, Reitsma WD, et al. Glycosylated hemoglobin and iron deficiency. Lancet 1980;2(8193):531-2.

[6] Coban E, Ozdogan M, Timuragaolgu A. The effect of iron deficiency anemia on the levels of hemoglobin A1c in nondiabetic patients. Acta Haematol 2004;112(3):126-8.

[7] Shendurnikar N. Iron deficiency is preventable http:\\ www. India Parenting. Com/ raising child/ data/ raising child 063. html 2007. 


\section{Jemds.com}

[8] Brooks AP, Metcalfe J, Day JL, et al. Iron deficiency and glycosylated hemoglobin A. Lancet 1980;2(8186):141.

[9] Mitchell TR, Anderson D, Shepherd J. Iron deficiency, haemochromatosis and glycosylated haemoglobin. Lancet 1980;2(8197):747.

[10] Van Heyningen C, Dalton RG. Glycosylated haemoglobin in iron deficiency anemia. Lancet 1985;1(8433):874.

[11] Gram-Hansen P, Eriksen J, Mourits-Anderson T, et al. Glycosylated hemoglobin (HbA1c) in iron and vitamin B12 deficiency. J Intern Med 1990;227(2):133-6.

[12] El-Agouza L, Abu Shahla A, Sirdah M. The effect of iron deficiency anaemia on the Levels of haemoglobin subtypes: possible consequences for clinical diagnosis. Clin Lab Haematol 2002;24(5):285-9.

[13] Sinha N, Mishra TK, Singh T, et al. Effect of iron deficiency anaemia on hemoglobin A1c levels. Ann Lab Med 2012;32(1):17-22.

[14] Bain BJ, Lewis SM. Dacie and Lewis practical haematology. $11^{\text {th }}$ edn. Edinburgh: Elsevier Churchill Livingstone 2012.

[15] Longo DL, Fauci AS, Kasper DL, et al. Harrisons Principles of internal medicine. Fig. no. 417-1. $18^{\text {th }}$ edn. Newyork: McGraw-Hill 2011: p. 2399.

\section{Original Research Article}

[16] Rajagopal L, Ganapathy S, Arunachalam S, et al. Does iron deficiency anaemia and its severity influence HbA1c level in non-diabetics? An analysis of 150 cases. Journal of Clinical and Diagnostic Research 2017;11(2):EC13-EC15.

[17] Shanthi B, Revathy C, Jagadeeshwaran A, et al. Effect of iron deficiency on glycation of hemoglobin in non diabetic. Journal of Clinical and Diagnostic Research 2013;7(1):15-17.

[18] Christy AL, Manjrekar PA, Babu RP, et al. Influence of iron deficiency anemia on hemoglobin A1C levels in diabetic individuals with controlled plasma glucose levels. Iranian Biomedical Journal 2014;18(2):88-93.

[19] Ford ES, Cowie CC, Li C, et al. Iron-deficiency anaemia, non-iron-deficiency anaemia and HbA1c among adults in the US. J Diabetes 2011;3(1):67-73.

[20] Saudek CD, Herman WH, Sacks DB, et al. A new look at screening and diagnosing diabetes mellitus. J Clin Endocrinol Metab 2008;93(7):2447-53. 